\title{
Analysis of Sedimentation in Wonogiri Reservoir
}

\author{
Tri Joko Inti Budi Santosa \\ Large River Basin Organization of Bengawan Solo, Surakarta, INDONESIA \\ trijokointibs@gmail.com
}

\begin{abstract}
The Wonogiri reservoir which has 730 million cubic meters of total storage, 90 square kilometers of water area, and 1,260 square kilometers of catchment area, is located in the Wonogiri Regency, Central Java Province. It was first established in 1981 and began its operation in 1982 with the expectation that it would last for about 100 years. Since 2002 the reservoir has got a serious problem of sedimentation. The sedimentation is so large that it would decrease the capacity storage of the reservoir and would shorten the length of operation. Therefore, it is necessary to predict the sediment inflow into the reservoir. This research was based on the total sediment calculations using several methods, such as echo sounding measurement data, surface soil erosion (USLE), and the calculation of the sediment flow in rivers. The amount of sediment was estimated by converting the discharge hydrograph to sediment hydrograph based on sediment rating curves in Keduang, Tirtomoyo, Temon, upper reach of Bengawan Solo, Alang, and Wuryantoro rivers. The suspended load was calculated based on the sediment rating curves, whereas the bed load was computed as the percentage of the suspended load. The sum of both calculation results would be the total sediment. The results show that the total sediment inflow into the reservoir is 6.68 million cubic meters per year. As a comparison, Faculty of Geography of Universitas Gadjah Mada in 1985 conducted the sedimentation analysis using echo sounding method found that the total sediment capacity which came into the reservoir was 6.60 million cubic meters per year, equal to $5.40 \mathrm{~mm}$ per year of sheet erosion. The other research using echo sounding method done by JICA in 2000 found that the total sediment inflow into the reservoir was 4.50 million cubic meters per year, equal to $3.50 \mathrm{~mm}$ per year of sheet erosion. These results indicate some values of sediment inflow rates that need to be carefully considered for the assessment of their treatment.
\end{abstract}

Keywords: sediment, Wonogiri Reservoir, sediment capacity in rivers

\section{INTRODUCTION}

The Wonogiri Reservoir is one of the reservoirs built in the Central Java. The construction started in 1976, finished in 1981, and began its operation in 1982. The size of the water area is about $90 \mathrm{~km}^{2}$, with storage volume of 730 million $\mathrm{m}^{3}$. The reservoir's catchment area is approximately $1,260 \mathrm{~km}^{2}$ which covers; Baturetno, Pracimantoro, and Wuryantoro Districts of Wonogiri Regencey.

In the Master Plan of Bengawan Solo River Basin Development Project (JICA, 1974 recited in (Bengawan Solo Project (PBS), 1987), it was predicted that the average sediment is 1.2 million $\mathrm{m}^{3} /$ year, or equal with sheet erosion of $1.17 \mathrm{~mm} /$ year. It is also mentioned that the reservoir construction also come with 46 unit check dam constructions, and also reforestation in around the reservoir (green belt).

To estimate the sediment in the reservoir, the method could be used are the echo sounding measurement, surface soil erosion calculation (Universal Soil Loss
Equation-USLE) (Wischmeier, 1959), and calculation on sediment in river; for the analysis, the existing secondary data was used, or the data that has been researched by several institute; the data were obtained from the Bengawan Solo River Basin Development Project. The purpose of this research was to estimate the useful life of Wonogiri Reservoir through sedimentation analysis using observed data of sediment in rivers, USLE and echo sounding methods. The analysis results are then was used to determine the proper alternative in handling the sedimentation issues.

\section{RESERVOIR SEDIMENTATION}

Sedimentation is a crucial problem commonly encountered in the management of reservoirs. It causes reduced service life of the reservoir due to the large sediment yield inside the reservoir. In case of Wonogiri Reservoir, there have been a lot of researches about sedimentation by several institutes, as seen in the Table 1 . 
Table 1. Several researches on sedimentation issues in Wonogiri Reservoir (Bengawan Solo Project (PBS) (1987), Bengawan Solo Project (PBS) 1986)

\begin{tabular}{|c|c|c|c|c|}
\hline No. & Institute & Prediction/Calculation & $\begin{array}{c}\text { Prediction of } \\
\text { Reservoir Useful } \\
\text { life (up to Year) }\end{array}$ & Note \\
\hline 1 & $\begin{array}{l}\text { JICA (Japan International } \\
\text { Cooperation Agency), } 1974\end{array}$ & $\begin{array}{l}\text { Average Sediment } 1.2 \text { million } \\
\mathrm{m}^{3} / \text { year equivalent to } 1.17 \\
\mathrm{~mm} / \text { year. }\end{array}$ & 2082 & $\begin{array}{l}\text { Wonogiri Reservoir } \\
\text { Planning }\end{array}$ \\
\hline 2 & $\begin{array}{l}\text { Research and Development } \\
\text { Center of Water Resources } \\
\text { (DPMA), } 1982 \text { and } 1984\end{array}$ & $\begin{array}{l}\text { Average Sediment } 5.2 \text { million } \\
\mathrm{m}^{3} / \text { year equivalent to } 4.1 \\
\mathrm{~mm} / \text { year }\end{array}$ & 2005 & $\begin{array}{l}\text { Prediction using USLE } \\
\text { formula }\end{array}$ \\
\hline 3 & $\begin{array}{l}\text { Faculty of Geography UGM, } \\
1984 \text { and } 1985\end{array}$ & $\begin{array}{l}\text { Average Sediment } 6.6 \text { million } \\
\mathrm{m}^{3} / \text { year equivalent to } 5.4 \\
\mathrm{~mm} / \text { year }\end{array}$ & 2000 & $\begin{array}{l}\text { Echo sounding } \\
\text { measurement on } 69 \\
\text { profiles }\end{array}$ \\
\hline 4 & PBS and Brantas Project, 1985 & $\begin{array}{l}\text { Average Sediment } 8.1 \text { million } \\
\mathrm{m}^{3} / \text { year equivalent to } 6.6 \\
\mathrm{~mm} / \text { year }\end{array}$ & 1997 & $\begin{array}{l}\text { Echo sounding } \\
\text { measurement on } 69 \\
\text { profiles }\end{array}$ \\
\hline 5 & $\begin{array}{l}\text { BRLKT Watersheds Solo, } \\
1985\end{array}$ & $\begin{array}{l}\text { Average Sediment } 6.6 \text { million } \\
\mathrm{m}^{3} / \text { year equivalent to } 5.4 \\
\mathrm{~mm} / \text { year }\end{array}$ & 2000 & $\begin{array}{l}\text { Prediction using USLE } \\
\text { formula }\end{array}$ \\
\hline 6 & JICA, 2000 & $\begin{array}{l}\text { Average Sediment } 4.5 \text { million } \\
\mathrm{m}^{3} / \text { year equivalent to } 3.5 \\
\mathrm{~mm} / \text { year }\end{array}$ & 2008 & $\begin{array}{l}\text { Echo sounding } \\
\text { measurement on } 16 \\
\text { profiles }\end{array}$ \\
\hline
\end{tabular}

\subsection{Sediment Classification}

Based on the transport method, sediment could be classified into suspended sediment (suspended load) and river bed sediment (bed load). Definition of suspended load sediment is sediment load that float in the river stream, and generally consists of fine sand, clay, and mud (Kironoto, 2002). The concentration of suspended sediment is stated in dry weight per volume of mixture in $\mathrm{mg} / \mathrm{liter}$; which varies in cross section of river flow. The coarse particles that move in along the river bed are called the bed load. The existence of the bed load shown with the particle movement in the river bed, which could be sliding, rolling, or hopping at the river bed.

\subsection{Sediment Discharge Curve}

Relation between suspended sediment discharge curve and stream discharge mostly could be described as follows:

$$
Q_{s}=a \times Q_{w}^{b}
$$

whereas $Q_{s}$ is suspended sediment discharge (ton/days), $Q_{w}$ is stream discharge $\left(\mathrm{m}^{3} / \mathrm{s}\right), a$ and $b$ are constants, which its value is depend on the measurement data on field.

The relation of both parameters could be plotted into a suspended sediment rating curve. This suspended sediment discharge curve is obtained from the plotting of stream discharge data $\left(Q_{w}\right)$ with suspended sediment discharge data $\left(Q_{s}\right)$ on the logarithmic scale graph, by using the power function of a regression analysis (Legono, 2002).

\section{3 (Bed Load)}

The scale of bed load discharge could be determine based on the equation written in several literatures, as in Meyer-Peter equation, Einstein, etc., or could practically be determined with on the Maddock (1953), which based on the suspended load calculation result as shown in Table 2 .

Table 2. Percentage of bed load transport to suspended sediment according to Maddock (1953)

\begin{tabular}{|c|c|c|c|}
\hline $\begin{array}{l}\text { Suspended } \\
\text { Sediment } \\
\text { Concentration } \\
(\mathrm{ppm})\end{array}$ & $\begin{array}{l}\text { Riverbed } \\
\text { Material } \\
\text { Type }\end{array}$ & $\begin{array}{l}\text { Texture of } \\
\text { Suspended } \\
\text { Material }\end{array}$ & $\begin{array}{l}\text { Percentage of } \\
\text { Bed Load } \\
\text { Transport to } \\
\text { Total } \\
\text { Suspended } \\
\text { Load }\end{array}$ \\
\hline$<1000$ & Sand & $\begin{array}{l}20 \%-50 \% \\
\text { Sand }\end{array}$ & $25-150$ \\
\hline $1000-7500$ & Sand & $\begin{array}{l}20 \%-50 \% \\
\text { Sand }\end{array}$ & $10-35$ \\
\hline$>7500$ & Sand & $\begin{array}{l}20 \%-50 \% \\
\text { Sand }\end{array}$ & 5 \\
\hline $\begin{array}{l}\text { Random } \\
\text { concentration }\end{array}$ & $\begin{array}{l}\text { Clay, } \\
\text { gravel }\end{array}$ & $\begin{array}{l}<25 \% \\
\text { Sand }\end{array}$ & $5-15$ \\
\hline $\begin{array}{l}\text { Random } \\
\text { concentration }\end{array}$ & Silt & $\begin{array}{l}\text { Without } \\
\text { Sand }\end{array}$ & $<2$ \\
\hline
\end{tabular}




\section{DATA AND ANALYSIS}

\subsection{Data}

The data used in this research is secondary data of reservoir inflow coming from the daily discharge of 6 rivers. Figure 1 depicts the probability curve of daily discharge of Keduang River according the observed data from 1981 to 1988 (River Investigation Agency, 1989). Other data that were obtained are suspended sediment rating curve, and the dry weight per unit volume (the specific weight) for 6 sub-watersheds in the Wonogiri Reservoir catchment area (Santosa, 2003).

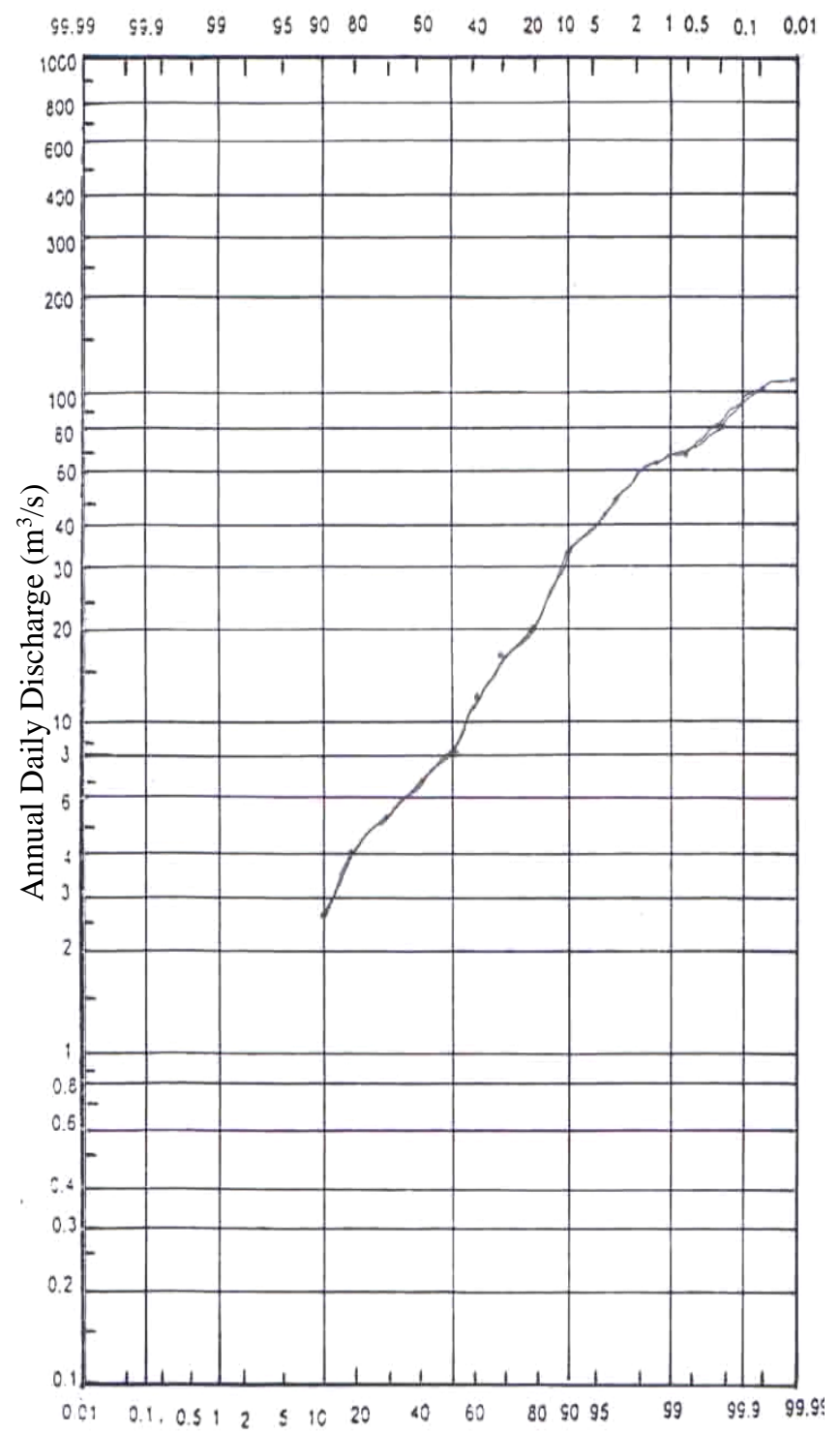

Figure 1. Discharge probability curve for Keduang River on January

Furthermore, by finding the river discharge and sediment content for each discharge, the suspended load volume then could be calculated. Sediment concentration $C$ in $\mathrm{mg}$ and water discharge $Q_{w}$ in $\mathrm{m}^{3} / \mathrm{sec}$ were obtained from measurement result, while Suspended Sediment Rating Curve in ton/days was estimated through Power Regression as a relation connecting between $Q_{w}$ and $Q_{s}$ (Equation (1)). The relation between water discharge and sediment discharge is as shown in Table 3.

Table 3. Regression of each river in Wonogiri Reservoir catchment area

\begin{tabular}{llllll}
\hline No & Watershed Name & $\begin{array}{l}\text { Area } \\
\left(\mathrm{km}^{2}\right)\end{array}$ & $\mathrm{a}$ & $\mathrm{b}$ & $\mathrm{r}$ \\
\hline 1 & Keduang & 426 & 3.101 & 2.118 & 0.956 \\
2 & Tirtomoyo & 206 & 5.107 & 2.592 & 0.968 \\
3 & Temon & 69 & 4.618 & 1.145 & 0.965 \\
4 & Upstream reach & 200 & 4.323 & 2.156 & 0.967 \\
& of Bengawan & & & & \\
& Solo & & & & \\
5 & Alang & 235 & 3.736 & 1.818 & 0.958 \\
6 & Wuryantoro & 73 & 15.611 & 2.008 & 0.978 \\
7 & Others & 51 & & & \\
\hline & Total & 1,260 & & & \\
\hline
\end{tabular}

\subsection{Analysis}

From the obtained data, the result was the discharge probability curve, as shown in Figure 1. The discharge probability curve then resulted in discharge quantity that was used to calculate the amount of sediment load in the river, as shown in Table 4 and Table 5. Based on the analysis result, the estimated annual suspended sediment load enter the reservoir is $723,560.94$ ton/year.

Table 4. Result analysis of monthly sediment in Keduang Watershed

\begin{tabular}{lllll}
\hline Month & $\begin{array}{l}Q_{w} \\
\left(\mathrm{~m}^{3} / \mathrm{sec}\right)\end{array}$ & $\begin{array}{l}\text { Total } \\
\text { Days }\end{array}$ & $\begin{array}{l}Q_{s} \\
\text { (ton/month) }\end{array}$ & $\begin{array}{l}\text { Concentration } \\
(C) \mathrm{mg}\end{array}$ \\
\hline Jan & 13.79 & 31 & 54526.80 & 1476.77 \\
Feb & 16.66 & 28 & 61722.65 & 1531.32 \\
Mar & 13.77 & 31 & 62007.80 & 1681.88 \\
Apr & 8.30 & 30 & 23460.59 & 1091.16 \\
May & 5.96 & 31 & 14140.55 & 885.45 \\
Jun & 4.62 & 30 & 7393.46 & 617.58 \\
Jul & 9.01 & 31 & 69769.19 & 2890.30 \\
Aug & 10.97 & 31 & 106459.99 & 2623.71 \\
Sep & 11.26 & 30 & 96283.55 & 3300.07 \\
Oct & 11.89 & 31 & 103648.71 & 3254.53 \\
Nov & 12.89 & 30 & 77539.95 & 2321.07 \\
Des & 11.51 & 31 & 46607.70 & 1512.33 \\
\hline Total & 130.63 & 365 & $723,560.94$ & \\
Average & 10.89 & & $60,296.74$ & $24,186.17$ \\
\hline
\end{tabular}

Not all of the suspended sediment loads that entered the reservoir will be deposited. Some of it would discharged from the reservoir through the spillway and intake tower as shown in Table 6. 
The trap efficiency, i.e. the ratio between the reservoir storage capacity and the annual inflow volume was applied to estimate the annual deposited sediment in the reservoir. Based on the analysis, the annual sediment load that entered the reservoir is 6.68 million $\mathrm{m}^{3} /$ year. Comparison of this research result with previous researches is shown in Table 7.

General prediction shown in Table 7 obtained by dividing volume of sediment input with the dead storage capacity of the reservoir which was $120 \times 10^{6}$ $\mathrm{m}^{3}$. Based on the review on the prediction of Wonogiri through sediment transport estimation and consideration of reservoir management, it was resulted that sediment volume entrained to the reservoir through the tributaries is about 6.68 million $\mathrm{m}^{3} /$ year. The remaining useful life of the reservoir was predicted to be around 18 years. The research result was good enough if compared with other methods, particularly the echo sounding method.

Table 5. Suspended sediment calculation on January in Keduang River watersheds

\begin{tabular}{|c|c|c|c|c|c|c|c|}
\hline No. & Limit $(\%)$ & Interval $(\%)$ & Medium Value (\%) & $Q w\left(\mathrm{~m}^{3} / \mathrm{s}\right)$ & $Q s$ (ton/days) & $Q w($ ton/days $)$ & Qs (ton/days) \\
\hline 1 & $0.00-0.02$ & 0.02 & 0.01 & 102.50 & 56261.97 & 0.02 & 11.25 \\
\hline 2 & $0.02-0.10$ & 0.08 & 0.06 & 100.00 & 53395.14 & 0.08 & 42.72 \\
\hline 3 & $0.10-0.50$ & 0.40 & 0.30 & 80.00 & 33284.83 & 0.32 & 133.14 \\
\hline 4 & $0.50-0.75$ & 0.25 & 0.63 & 68.50 & 23960.42 & 0.17 & 59.90 \\
\hline 5 & $0.75-1.50$ & 0.75 & 1.13 & 62.50 & 19732.21 & 0.47 & 147.99 \\
\hline 6 & $1.50-5.00$ & 3.50 & 3.25 & 50.00 & 12300.43 & 1.75 & 430.51 \\
\hline 7 & $5.00-15.0$ & 10.00 & 10.00 & 32.50 & 4939.36 & 3.25 & 493.94 \\
\hline 8 & $15.0-25.0$ & 10.00 & 20.00 & 20.00 & 1766.38 & 2.00 & 176.64 \\
\hline 9 & $25.0-35.0$ & 10.00 & 30.00 & 17.50 & 1331.24 & 1.75 & 133.12 \\
\hline 10 & $35.0-45.0$ & 10.00 & 40.00 & 12.50 & 652.77 & 1.25 & 65.28 \\
\hline 11 & $45.0-55.0$ & 10.00 & 50.00 & 8.00 & 253.66 & 0.80 & 25.37 \\
\hline 12 & $55.0-65.0$ & 10.00 & 60.00 & 7.00 & 191.17 & 0.70 & 19.12 \\
\hline 13 & $65.0-75.0$ & 10.00 & 70.00 & 5.50 & 114.71 & 0.55 & 11.47 \\
\hline 14 & $75.0-85.0$ & 10.00 & 80.00 & 4.00 & 58.43 & 0.40 & 5.84 \\
\hline 15 & $85.0-95.0$ & 10.00 & 90.00 & 2.75 & 26.42 & 0.28 & 2.64 \\
\hline 16 & $95.0-98.5$ & 3.50 & 95.75 & & & & \\
\hline 17 & $98.5-99.5$ & 1.00 & 99.00 & & & & \\
\hline 18 & $99.5-99.9$ & 0.40 & 99.70 & & & & \\
\hline 19 & 99.9 - 99.98 & 0.08 & 99.94 & & & & \\
\hline 20 & $99.98-100$ & 0.02 & 99.99 & & & & \\
\hline Total & & & & & & 13.79 & 1758.93 \\
\hline
\end{tabular}

Table 6. Recapitulation on the annual suspended sediment discharge

\begin{tabular}{llllll}
\hline No & Watershed Name & Area $\left(\mathrm{km}^{2}\right)$ & $\begin{array}{l}\text { Suspended sediment } \\
\text { load discharge 85\% } \\
\text { (ton/year) }\end{array}$ & $\begin{array}{l}\text { Bed Load Sediment } \\
\text { Discharge (ton/year) }\end{array}$ & $\begin{array}{l}\text { Sediment Load Total } \\
\text { Discharge (ton/year) }\end{array}$ \\
\hline 1 & Keduang & 426 & $615,028.90$ & $180,890.24$ & $795,917.17$ \\
2 & Tirtomoyo & 206 & $2,458,694.28$ & $723,145.25$ & $3,181,839.65$ \\
3 & Temon & 69 & $34,746.60$ & $10,219.54$ & $44,966.19$ \\
4 & Upstream reach of B. & 200 & $98,527.55$ & $28,978.74$ & $127,506.24$ \\
& Solo & & & & \\
5 & Alang & 235 & $198,202.56$ & $58,294.97$ & $256,497.43$ \\
6 & Wuryantoro & 73 & $259,299.81$ & $76,264.60$ & $335,564.46$ \\
7 & Others & 51 & $148,324.89$ & $43,624.97$ & $191,949.86$ \\
\hline
\end{tabular}


Table 7. Research results comparison

\begin{tabular}{|c|c|c|c|c|}
\hline \multirow{2}{*}{ Institute } & \multicolumn{2}{|c|}{$\begin{array}{l}\text { The Annual } \\
\text { Sedimentation }\end{array}$} & \multirow{2}{*}{$\begin{array}{l}\text { Reservoir Useful } \\
\text { life Prediction } \\
\text { (up to year) }\end{array}$} & \multirow{2}{*}{ Note } \\
\hline & $\begin{array}{l}\text { (million } \\
\mathrm{m}^{3} / \text { year) }\end{array}$ & $\begin{array}{l}(\mathrm{mm} / \\
\text { year })\end{array}$ & & \\
\hline $\begin{array}{l}\text { JICA, } \\
1974\end{array}$ & 1.20 & 1.17 & $100(2082)$ & USLE \\
\hline $\begin{array}{l}\text { DPMA, } \\
1985\end{array}$ & 5.20 & 4.10 & $23(2005)$ & USLE \\
\hline $\begin{array}{l}\text { UGM, } \\
1985\end{array}$ & 6.60 & 5.40 & $18(2000)$ & $\begin{array}{l}\text { Echo } \\
\text { sounding }\end{array}$ \\
\hline $\begin{array}{l}\text { PBS, } \\
1985\end{array}$ & 8.10 & 6.60 & 15 (1997) & $\begin{array}{l}\text { Echo } \\
\text { sounding }\end{array}$ \\
\hline $\begin{array}{l}\text { BRLKT, } \\
1985\end{array}$ & 6.60 & 5.40 & $18(2000)$ & USLE \\
\hline $\begin{array}{l}\text { JICA, } \\
2000\end{array}$ & 4.50 & 3.50 & $8(2008)$ & $\begin{array}{l}\text { Echo } \\
\text { sounding }\end{array}$ \\
\hline Research & 6.68 & & $18(2000)$ & $\begin{array}{l}\text { River } \\
\text { Sediment }\end{array}$ \\
\hline
\end{tabular}

\section{CONCLUSIONS AND SUGGESTIONS}

\subsection{Conclusions}

From the analysis results, several things could be concluded, such as follows:

a) The annual volume of the sediment that entered the reservoir is 6.68 million $\mathrm{m}^{3} / \mathrm{year}$.

b) Tirtomoyo River is the main source of Wonogiri Reservoir sediment; this river deposited sediment with the amount of 3,181,839.65 ton/year.

\subsection{Suggestions}

Several suggestions that could be recommended are as follows:

a) The prediction method of reservoir sedimentation based on sediment load in river was good enough when compared with other methods.

b) As in the case of such huge sedimentation, and incompatibility of master plan and realization in the field, vegetative and mechanical sediment counter measure in the reservoir catchment area is needed, particularly in the area that was identified to be the main source of the sediment.

\section{REFERENCES}

Bengawan Solo Project (PBS), 1986. Sedimentation in Wonogiri Reservoir, Surakarta: PBS.

Bengawan Solo Project (PBS), 1987. Monitoring dan Evaluasi Sedimentasi Waduk Wonogiri [Monitoring and Evaluation on Sedimentation in Wonogiri Reservoir], Surakarta: PBS.

Kironoto, B., 2002. Prediksi dan Evaluasi Erosi [Evaluation and Prediction of Erosion], Yogyakarta: Master of Engineering in Natural Disaster Management, UGM.

Legono, D., 2002. River Sedimentation, Yogyakarta: Master of Engineering in Natural Disaster Management, UGM.

River Investigation Agency, 1989. Monitoring Erosi DAS Waduk Wonogiri [ Monitoring of Erosion in Wonogiri Watershed], Surakarta: River Investigation Agency.

Santosa, T. J. I. B., 2003. Prediksi Sedimentasi Waduk Wonogiri melalui Angkutan Sedimen di Sungai [Sedimentation Analysis of Wonogiri Reservoir through Sediment Transport Estimation in the Upstream River], Yogyakarta: Universitas Gadjah Mada.

Thomas Maddock, J. \& Leopold, L. B., 1953. Relation of suspended-sediment concentration to channel scour and fill. Iowa, pp. 159-178.

Wischmeier, W., 1959. A rainfall erosion index for a universal soil-loss equation. USA, pp. 246-249. 
[this page intentionally left blank] 